FACTA UNIVERSITATIS

Series: Physical Education and Sport, Vol. 18, No 3, 2020, pp. 515 - 523

https://doi.org/10.22190/FUPES200918049C

Narrative review article

\title{
MOTOR AND INTELLECTUAL DEVELOPMENT IN CHILDREN: A REVIEW
}

UDC 796.012.1:165.19-053.5

\author{
Milan Čoh \\ Faculty of Sport, University of Ljubljana, Ljubljana, Slovenia
}

\begin{abstract}
The aim of this narrative review article is to present the effects of physical activity on the motor and cognitive development of children. Early childhood is one of the most critical periods in a child's physical and intellectual development. As much as seventy percent of the brain's connections develop during the pre-school years, these connections form the basis and framework for the child's later abilities and characteristics. A physically stimulating and varied environment undoubtedly has a significant impact on the mental functions of children. The brain is designed to learn and solve problems, initially simple, later complex. The earliest challenges that the brain needs to solve are related to movement. Children solve these problems spontaneously, intuitively, and in an unstructured manner. Later, with more organized movements, children acquire various motor skills, abilities, and sensory experiences, thereby gaining a new understanding of themselves and their surroundings. These insights and experiences will equip the child for the challenges and problems they will face later in life. Children enter into social interactions and group dynamics through movement and acquire a sense of autonomy and independence. A stimulating and varied motor environment undoubtedly has a significant impact on children's intellectual function and, thus, on the development of their potential abilities.
\end{abstract}

Key words: Motor Development, Cognitive Development, Physical Activity, Children

\section{INTRODUCTION}

Children have a biological need to move. The World Health Organization (2004) recommends that children and adolescents are physically active for 60 to 90 minutes a day. However, this is often not the case. Modern consumer-oriented lifestyles, fun electronic and communication products have caused a devastating movement deficit in young people. Children spend a lot of their time in the virtual world in front of computers, tablets, and

Received September 18, 2020/ Accepted December 10, 2020

Corresponding author: Milan Čoh

Faculty of Sport, University of Ljubljana, Gortanova ul. 22, 1000 Ljubljana, Slovenia

Phone: + 38615207700 • E-mail: Milan.Coh@fsp.uni-lj.si

ㄷ 2020 by University of Niš, Serbia | Creative Commons License: CC BY-NC-ND 
other "wonders" of the modern world. The consequences are obvious and evident in many fields. The SLOfit project (Slovenian National System for Monitoring the Physical and Motor Development of Children and Youth), a longitudinal study conducted by the Faculty of Sports, University of Ljubljana, showed that we have more and more overweight children in Slovenia. Compared to other countries of the European Union, Slovenian children and adolescents fall into the critical group of those with increased body weight. In 2015/2016, it was established that about $20 \%$ of boys aged 10 to 13 and about $18 \%$ of girls in the same age category were overweight (Starc, Strel, Kovač, Leskošek, Sorić, \& Jurak, 2016). As a result, children are less physically fit than decades ago, especially in various motor skills. Our teenagers (11-14 year olds) run $600 \mathrm{~m} 8$ seconds slower than their counterparts of 40 years ago (Škof \& Tvan, 2016). The aerobic $600 \mathrm{~m}$ run is one indicator of a child's general motor efficiency and functional ability, especially pertaining to the vascular and respiratory systems. Slovenian children's physical efficiency is declining, the portion of less physically competent children is increasing, and their number has doubled in the past twenty years (Strel, Jurak, Starc, \& Strel, 2016; Starc et al., 2016).

Childhood health is often correlated with being overweight and having a lower level of motor skills. Lack of physical activity (PA), an unhealthy diet, and poor physical fitness directly jeopardize children's health. Today, heart disease, metabolic diseases, and type 2 diabetes pose serious health, paediatric, and social problems for Slovenian children (Škof, 2016). Why are physical activities the right choice for kids? Because they not only strengthen muscles, the heart, and lungs, but they also present opportunities for peer collaboration, biological development, intellectual, psycho-social, and mental development on which happiness and satisfaction of children are based. Physically less successful and less physically active children also have lower academic achievements than more physically able and active children (Strel et al., 2016). Physical - sports activities help young people develop into creative individuals with core values. Children and adolescents who are physically active create significant health capital for adulthood. Regular PA in youth encourages greater care for a healthy lifestyle later in life.

The aim of the research is to determine the effects of the PA on the motor and cognitive development of the children.

\section{THEORETICAL CONSIDERATIONS OF THE PROBLEM}

Recently, there have been many new insights related to the mental development of children. Scientific discoveries in neuroscience, neurophysiology, cognitive psychology, kinesiology, and modern paediatrics show new aspects of the development of children's potential. The development of human biological potential is a complex and dynamic process that requires the systematic cooperation of several factors, among which the individual, genetic, family, and social environments play a decisive role (Renzulli, 1986; Hannon, 2003). For brain development, the pre-school period is crucial in the dynamics of this process. The human brain is the result of its evolution; it is the organ that enables us to survive. The only constant of the brain is its ability to change and adapt to its given circumstances. Humans are the product of millions of years of adaptation to natural and social environments. While our ancestors lived on cliffs, collecting food and hunting animals, running was a necessary part of their lives. The brain was a "luxury" organ that required a lot of energy, and this needed to be ensured by providing it with enough food 
to keep the brain functioning optimally. Scientists have found (Lieberman, 2015) that it was running in those prehistoric times that enabled our ancestors' brain development because they were more successful at finding food by running. Brain development depended primarily on the increased amount of protein that humans could obtain by hunting and eating animals. The only "weapon" that Homo erectus had was fast legs. With a larger brain, they could generate more knowledge, more complex cognitive and social behaviours, including speech and collaboration (Lieberman, 2015). As such, their development into more successful hunters and gatherers gave them a much better chance of survival. Smarter hunters and gatherers were able to interact better with each other, create more significant energy surpluses. In subsequent evolutionary periods, the brain evolved through natural selection. The "running gene" is still present in humans today, and this is especially evident in children (Eynon et al., 2013).

The brain is a gelatinous organ hidden within the skull, whose function is so complex that many aspects still cannot be explained. The average human brain weighs 1,400 grams, accounting for about $2 \%$ of the average human body weight. However, it consumes as much as $20 \%$ of all the oxygen available to our body (Bregant, 2011). A new-born's brain weighs about 300 grams, which is $10 \%$ of their body weight. Recent neuroscientific research shows that $50 \%$ of intelligence is hereditary, and one's environment influences the rest. We have approximately 100 billion nerve cells (neurons) in the brain that communicate with each other through connections (synapses). At birth, each neuron in the cerebral cortex has about 2,500 synapses, with the number increasing to 15,000 within the first two years of life (Bregant, 2011). An infant's brain consumes around 100 calories per day, which is $60 \%$ of their daily resting energy expenditure. The adult brain consumes between 280 and 420 calories per day, which is 20 to $30 \%$ of a person's daily resting energy expenditure (Lieberman, 2015).

During the first month of life, the total number of the brain's synapses increases from 50 trillion to 1 quadrillion (Bregant, 2010). Synapses are a dynamic system; they are formed, strengthened, or even lost if not properly stimulated. This phenomenon is called "brain neuroplasticity". The synapses we use more often are preserved, the ones we use less disappear (Bregant, 2012; Bregant, 2011).

The brain is in constant functional change; it is like a "construction site". We strengthen it through training, we weaken it with non-training. Synapses - connections can become thicker, thinner, or deteriorate altogether. According to some research, the critical period of intellectual development happens in early childhood from 2 to 5 years of age. More than $70 \%$ of synapses develop in this pre-school period. Research shows that an individual's intellectual abilities depend not only on the number of nerve cells but also on the number of synapses (Volpe, 2008; Rajović, 2016a). Maturation and development of the brain - synapses are formed most intensively up to the fifth year (50\%), up to the seventh year (70\%), and up to the twelfth year of life $(95 \%)$. Brain development is thus most intense in the first few years of life when neurons combine into neural networks of interconnections. Inside the brain, there is a constant struggle for dominance in which new connections are created between active neurons (nerve cells). Inactive neurons die, and inactive neural pathways are lost forever.

The number of connections between neurons increases through activity, which is reflected in the density of the neural network within the brain. How do we stimulate neural functioning and connection formation? A child's brain is a highly absorbent "sponge" that receives various stimuli from its surroundings. In early childhood, the child 
processes information about the image, sound, and feel of an object as a whole (Rajović, $2016 \mathrm{~b}$ ). As a child begins to perceive his or her surroundings, new connections between nerve cells begin to establish. The more stimulating the environment a child lives in, the greater the number of created synaptic connections. During the first years of life, the basics of thinking, language, sight, hearing, taste, and physical skills are developed. A child receives many visual, auditory, tactile, and motor stimuli from the environment through innate primary ontogenetic motor skills such as crawling and climbing (Malina, Bouchard, \& Bar-Or, 2004; Videmšek \& Pišot, 2007; Pišot, 2012). For humans, learning is a life-long process, but the foundations are formed in early childhood. The child is an explorer.

Due to the high brain plasticity in early childhood, susceptibility to environmental factors and lifestyle is significant in growing and developing children (Rajović, Berić, Bratić, Živković, \& Stojiljković, 2016).

A stimulating environment allows for the development of synapses and denser neural networks, which form the basis for mental development later on. From a multitude of sounds, a child uses only those they hear in the environment. The most common, and simultaneously one of the most difficult mental challenges for a child is their mother's voice. Between the second and third years of age, the child can already recognize colours and symbols. The importance and effects of early childhood activity can be seen by studying certain cultures with exceptional abilities. Eskimos can distinguish between fifteen shades of white from the age of five. This ability is related to their observation of ice and snow. The Maori people are known to be extremely musical. Mothers sing songs to their children during pregnancy and later into childhood. Music and dancing are said to run in the blood of the Romani people.

\section{The importance of elementary PA for the overall development of children}

The first problems the brain needs to solve are related to movement. The child must find a suitable motor solution for reaching a toy through a developed perception of their own body. These are the initial cognitive processes associated with movement. The brain is created to learn and solve problems, initially simple, later complex (Gardner, 1995; Epstein, 2015, Bregant, 2011). The child solves these problems spontaneously, intuitively, and in an unstructured manner. Later, with more organized movement, the child acquires various motor skills and sensory experiences, thus creating a new understanding of itself and its surroundings. These insights and experiences will equip the child to better deal with the challenges and problems life brings. Through movement, children also enter into mutual interactions, group dynamics, and acquire a sense of autonomy and independence.

The basic human characteristics are walking upright and the ability to speak, which evolutionarily separate us from other animals. Man is otherwise a rather helpless mammal. While a foal or fawn can walk immediately after birth, it takes a human baby a year or more to learn to walk. PA is not only good from a health perspective but also for academic achievement. If a child spends a lot of time being passive, sitting, or lying down, there is a high possibility of developing cognitive problems later on. Each hour of sitting should be replaced by two hours of play or other PA (Rajović, 2016b). The child learns through active participation.

The best practice for walking is walking, the best practice for running is running, the best practice for skiing is skiing. Every time a child performs a new activity, new connections are formed in the brain. Through the repetition of a learned movement, the established brain 
connections are strengthened. Therefore, it is necessary to allow children as many different motor activities as possible, such as crawling, climbing, rolling, walking, running, jumping, balancing, and spinning. "Chinese jump rope" is one of the most complex and useful exercises for children. It includes the so-called intuitive movements, which are usually associated with children's play. Kids learn through play. When a child is immersed in play, many associative connections between neurons are established during the brain's REM state, when information is edited, consolidated, and stored into the corresponding memory bank. Movements, in the form of games, trigger the release of special substances in the brain - transmitters that give the child a feeling of happiness, comfort, and satisfaction.

Of particular importance in a child's movement development is exploration in nature. Jean Piaget, the father of developmental psychology, understood and defined childhood as a time when we are particularly motivated to explore nature. The assumption is that a child is emotionally and mentally in equilibrium when they are in nature. Evolutionarily, Homo sapiens have always learned from nature and adapted to natural laws.

Parents often make mistakes because of a lack of knowledge or fear that they will get hurt while playing. Parents are often overprotective of their children. This results in a child not having enough encouragement, not being active enough, thus not gaining new experiences necessary for his or her mental and personal development. We need to let kids play in the mud, sand, trees, or water. Let them get dirty.

Play is an essential factor in human mental development, providing emotional capital and mental "software" (Brussoni, 2019). It is not unique to humans, games and play are also present in animals. Paediatric research has found how important a child's contact with nature is, as this is where they encounter unsupervised play, risky play, and play with their peers. Many parents and their children live without direct contact with nature. Depression or phobias in adulthood often result from a lack of play in childhood. The child needs to be given a choice of play, including risky play. Enjoying freedom of movement with a certain amount of fear creates a mixture of excitement and curiosity (Marjanovič-Umek \& Zupančič, 2001). Risky games such as climbing, jumping, rollerblading, cycling, hiding, and similar activities involve intense attention and concentration, while primarily developing the prefrontal cortex the frontal lobe of the brain which is home to intellectual processes, associations, coordination, and global motor skills (Brussoni, 2019). In the last few years, there has been a dramatic reduction in children's opportunities to play freely, without adult supervision or with the possibility of a little risk. Their parents did not grow up being allowed to play risky games, and as a result, they do not let their children play in this way, for fear of them getting hurt. However, risky play has an evolutionary foundation. During human development, man has had to overcome fear, solve dangerous situations, seek solutions in cruel nature, and stay emotionally balanced to survive (Brussoni, 2019).

Thus, parents have the most significant role and responsibility for the development of their child's abilities. They spend the most time with the child and are most closely attached to it. The more encouragement to move they receive from their parents, the denser the neural networks will become. Inactivity results in fewer connections between neurons and gaps form in the structure of the brain. Separate areas of the brain have specialized functional centres (speech, fine motor skills - graphomotor skills, balance, sensorimotor skills). Depending on which part of the brain these gaps occur, the results can be seen in school as various learning difficulties, dyslexia, speech impairments, reading difficulties, lack of concentration, and motor incompetence. 
According to some research, about $50 \%$ of children have problems with fine motor skills - graphomotor skills (Rajović, 2016b). While global motor skills are related to the coordination and control of moving different parts of the body, fine motor skills result from the connection and coordination of the palms of the hands, fingers, and eyes. Indications of development in this ability are writing, drawing, and manual dexterity. The period from 2 to 7 years of age is vital for the development of fine motor skills. Graphomotor skills are important for the activation and stimulation of the cerebral cortex and, thus, for the child's general intellectual development (Rajović, 2016b). Sculpting playdough, handling various objects such as balls, sticks, blocks, daily tasks such as feeding, dressing, tying shoelaces, all develop fine motor skills. Graphomotor skills are made up of several different abilities, the most important of which are: visual perception, visual-motor coordination, kinaesthetic feedback, along with voice synthesis and analysis. For a child to start writing, which is one of the most demanding graphomotor activities, they must first undergo complete motor development. This begins with gross - global motor skills (sitting, crawling, walking, and running) and continues with fine motor skills, palm, and finger control. Graphomotor skills are fundamental to the development of synapses in the brain. As such, they are important for the development of a child's potential.

Sophisticated and coordinated hand movements act directly on the sensorimotor development of the nervous system and, through it, on speech development, which represents the highest level of sensorimotor coordination. By stimulating general motor skills, we directly influence the development of speech organs (Malina et al., 2004). Throughout history, hands made up of numerous bones, joints, and ligaments, have created superior works in art, painting, sculpture, architecture, music, engineering, and medicine. The child must first master coordinated and harmonious kinaesthetic control of hand movements. Development begins with moving the hand away from the body and the thumb away from the palm. The child first learns to catch larger objects (a ball) and later smaller ones. Undoubtedly, playing and manipulating various objects (balls of different shapes, sizes, weights, sticks, jump ropes, blocks, and other small props) has extremely positive effects on fine motor skills (Videmšek \& Pišot, 2007; Pišot, 2012). Kinaesthetic memory develops through the development of finger motility. The final phase of sensibilization and differentiation of finger motor skills is the mastery of graphomotor skills, i.e., writing and drawing.

Further, neuroscientists studying the development of the nervous system find that the development of children's speech is related to finger motor skills development. When the development of fine motor skills lags behind, the development of speech also lags behind. The influence of impulses from the muscles of the hands affects the formation of motor speech functions. For this reason, diverse activities such as shaping playdough, stacking blocks, or other objects, gluing, cutting, and doing other various crafts are essential. The hands send important information to the central nervous system and are involved in human communication in both verbal and kinaesthetic expression.

Do modern "electronic toys" such as phones, iPads and other electronic tablets also develop fine motor skills? Only partially since we only activate two fingers while using them. However, the effective development of graphomotor skills requires the activity of the entire palm and all our fingers. A rich and stimulating environment is needed for a child's holistic, motor, and intellectual development. Does school, in which children spend more than a third of their active time, fit into this environment? A frequent comment made by children and adolescents is "I don't like school", or even "I hate it." The famous humanist, pedagogue, and philosopher Jan Amos Komensky wrote: "School must be a game." But is it? Children often 
experience acute stress in the school environment. They have to learn large amounts of data, repeat it, memorize it, and eventually demonstrate its mastery. It is a reproductive mode of learning that is at odds with the functional operating of the brain. Our brain works on the principles of associations, comparisons, and image memory. Our school system has recently started to take heed of this with so-called interactive lessons. Associative learning provides functional knowledge or functional literacy, which is vital for the effective understanding of texts, the use of acquired information in everyday life, the recognition of essential natural laws, and sensibility of any conclusions.

According to the PISA (Program for International Student Assessment) for 2019, Slovenian students exceeded the average of their peers from other members of the OECD in the subject areas of mathematics, reading literacy, and tasks based on problem-solving. Every year, 540 thousand 15-year-olds from 72 countries are involved in the international PISA project. In recent years our students have shown progress mainly in reading literacy. The best students come from China, Singapore, Japan, Estonia, and Finland (Programme for International Student Assessment (n.d.).

The effective development of a nation's brain potential will decide the future perspective of a nation (Rajović, 2016b). Only associative learning creates new brain connections and, thus, creative and successful individuals.

What does modern life bring? Children spend more and more time in front of TVs, computers, iPads, and other electronic and communication devices. Their world of communication is no longer real; their world is artificial - virtual. This, too, has already shown consequences. In his book, the German researcher Manfred Spitzer (2016) talks about the socalled "digital dementia" of young people, resulting from modern visual and communication technologies. When children look at a screen, they perceive the image as one-dimensional planar, thus not activating dynamic accommodation - an adaptation of vision. As this means that the child is not developing balance, the eyes are not following the movement of the objects, and the child is not pursuing an object that is approaching or moving away from him or her. As such, the eye is not sending realistic images of the outside world to the visual centre located at the back of the brain. Unmodified vision can also cause problems with reading and writing, and consequently, communication and speech.

Walking, running, jumping, climbing, spinning, bowling, cycling, and other dynamic exercises keep the brain active, as they require balance. Children do not walk, run, and move enough in their natural environment. Walking barefoot was a habit for many past generations that children today hardly know of, even though barefoot walking and running on grass or sand develop a proper arch of the foot most effectively. A five-year-old child can walk four or more miles a day. According to some data, as many as $60 \%$ of children today have flat feet or a predisposition for flat feet. Fifty years ago, the percentage of children with flat feet was only $15 \%$ (Rajović, 2016b). This is clearly due to the lack of natural movements such as walking and running and exacerbated by inappropriate footwear. Adult hypokinesia and, more recently, of children, undoubtedly has increasingly visible consequences, reflected in the reduced quality of life of modern man. 


\section{CONCLUSION}

The development of children's mental and motor potential is a dynamic process related to many factors, among which family, pre-school institutions, schools, a stimulating social environment, and, last but not least, genetics, play decisive roles. Technological progress and the development of modern science allow us to understand children's mental and psychophysical development better. Early childhood is one of the most critical periods of a child's development. During the pre-school years, most of a person's brain connections develop, forming the framework for the child's later characteristics and abilities. A stimulating and varied motor environment undoubtedly has a significant impact on children's intellectual function and, thus, on the development of their potential abilities.

\section{REFERENCES}

Bregant, T. (2010). Razvoj možganov (Brain development). Proteus, 73(4), 168-174. In Slovenian Bregant, T. (2012). Brain development, growth, and maturation. Horizons of Psychology, 21(2), 51-60.

Bregant, T. (2011). Razvoj možganov in vzgoja otrok skozi oči nevroznanosti (Brain development and child rearing through the eyes of neuroscience). Retrieved Avgust 20, 2020 from the World Wide Web: www.sinapsa.org/eSinapsa/stevilke/2015-9/159/Razvoj+možganov+in+vzgoja+otrok+skozi+oči+ nevroznanosti. In Slovenian

Brussoni, M. (2019). Risky play for children: why we should let kids go outside and then get out of the way. Retrieved Avgust 23, 2020 from the World Wide Web: https://www.cbc.ca/natureofthings/features/risky-playfor-children-why-we-should-let-kids-go-outside-and-then-get-out

Epstein, D. (2015). Športni gen: talent, trening in resnica o uspehu (The sports gene: Talent, practise and truth about success). UMco.d.d. In Slovenian

Eynon, N., Hanson E., Lucia, A, Houweling, P., Garton F, North, K., et al. (2013). Genes for elite power and sprint performance: ACTN3 leads the way. Sports Medicine, 43(9), 803-817.

Gardner, H. (1995). Razsežnosti uma. Teorija o več inteligencah (Dimensions of the mind. Multiple intelligence theory). Tangram. In Slovenian

Hannon, P.(2003). Developmental neuroscience implication for early childhood invention and education. Current Paediatrics, 13(1), 58-63.

Lieberman, D. (2015). Zgodba človeškega telesa. Evolucija, zdravje in bolezen (The story of the human body. Evolution, health and disease). UMco, Ljubljana. In Slovenian

Marjanovič-Umek, L., \& Zupančič, M. (2001). Psihologija otroške igre (Psychology of children's play). Ljubljana: Faculty of Philosophy. In Slovenian

Malina, R., Bouchard, C., \& Bar-Or, O. (2004). Growth, maturation and physical activity. Human Kinetics.

Programme for International Student Assessment (n.d.). PISA. Retrieved September 2, 2020, at the World Wide Web: https://www.oecd.org/pisa/.

Pišot, R. (2012). Child in motion for healthy aging. In: R. Pišot, P. Dolenc, I., Retar, \& S. Pišot (Eds.) Proceedings of the 7th International Scientific and Expert Symposium „Child in motion for Healthy aging“, Koper.

Rajović, R. (2016a). IQ - Deteta - briga roditelja (IQ - Child - parental care). Smart Production, Novi Sad, Mensa Slovenije. In Serbian

Rajović, R. (2016b). Kako z igro spodbujati miselni razvoj otroka (How to stimulate a child's mental development through play). Mladinska knjiga, Ljubljana. In Slovenian

Rajović, R., Berić, D., Bratić, M., Živković, M., \& Stojiljković, N. (2016). Effects of an “NTC” exercise program on the development of motor skills in preschool children. Facta Universitatis Series Physical Education and Sport, 14(3), 315-329.

Renzulli, J. (1986). The three-ring conception of giftdness: a developmental model for creating productivity. Conceptions of gifttedness. London, Cambridege University Press.

Starc, G., Strel,. J., Kovač, M., Leskošek, B., Sorić, M., \& Jurak, G. (2016). Telesni in gibalni razvoj otrok v Sloveniji. Školsko leto 2015/2016 (Physical and motor development of children in Slovenia. School year 2016/2016). Ljublana: Faculty of Sports. In Slovenian

Strel, J., Jurak, G., Starc, G., \& Strel, J. (2016). Telesna zmogljivost za boljše zdravje in počutje : vloga osnovnega zdravstva in lokalne skupnosti pri zagotavljanju ustrezne telesne zmogljivosti po vrhniškem modelu (Physical fitness for better health and well-being: The role of primary health care and the local community in providing 
adequate physical fitness according to a peer model). In: Strel, J., Mišič, G., Strel, J., \& Glažar, T. (Eds.), Telesni fitnes $v$ funkciji zdravja (Physical fitness in the function of health). Logatec: Fitlab. In Slovenian

Spitzer, M. (2016). Digitalna demenca (Digital dementia). Ljubljana: Mohorjeva družba. In Slovenian

Škof, B., \& Țvan, B. (2016). Gibanje in gibalni razvoj. Śport po meri otrok in mladostnikov, 2. dopolnjena izdaja (Movement and motor development. Custom sports for children and adolescents, $2^{\text {nd }}$ Updated Edition), (pp. 304-343). Ljubljana: University of Ljubljana, Faculty of Sports. In Slovenian

Volpe, J. ( 2008). Neurology of the newborn. Philadelphia: Saunders Elsevier.

Videmšek, M., \& Pišot, R. (2007). Šport za najmlajše (Sport for the youngest). Ljubljana: Faculty of Sports, Institute of Sports. In Slovenian

World Health Organization (2004). Global strategy on diet, physical activity and health. Geneva: World Health Organization

\section{MOTORIČKI I INTELEKTUALNI RAZVOJ DECE: PREGLED}

Cilj ovog narativnog preglednog rada je da se predstave efekti fizičke aktivnosti na motorički $i$ kognitivni razvoj dece. Rano detinjstvo je jedan od najkritičnijih perioda detetovog fizičkog $i$ intelektualnog razvoja. Čak sedamdeset posto moždanih veza razvija se tokom predškolskih godina, te veze čine osnovu i okvir za kasnije detetove sposobnosti i karakteristike. Fizički podsticajno $i$ raznovrsno okruženje nesumnjivo ima značajan uticaj na mentalne funkcije dece. Mozak je dizajniran da uči i rešava probleme, u početku jednostavne, a kasnije složene. Najraniji izazovi koje mozak treba da reši povezani su sa kretanjem. Deca ove probleme rešavaju spontano, intuitivno $i$ na nestrukturiran način. Kasnije, organizovanijim pokretima, deca stiču različite motoričke veštine, sposobnosti $i$ čulna iskustva, čime stiču novo razumevanje sebe i svoje okoline. Ovi uvidi i iskustva osposobiće dete za izazove i probleme sa kojima će se suočiti kasnije u životu. Deca kreću u socijalne interakcije i grupnu dinamiku i stiču osećaj samostalnosti i nezavisnosti. Podsticajno i raznovrsno motoričko okruženje nesumnjivo ima značajan uticaj na intelektualnu funkciju dece, a time i na razvoj njihovih potencijalnih sposobnosti.

Ključne reči: motorički razvoj, kognitivni razvoj, fizička aktivnost, deca 